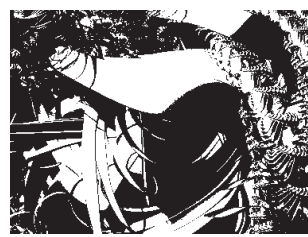

\title{
UVJERENJA JAVNOSTI O ISPRAVNIM RODITELJSKIM POSTUPCIMA PREMA DJECI NAJMLAĐE DOBI
}

Ninoslava PEĆNIK

Pravni fakultet, Zagreb

Tanja RADOČAJ

Ured UNICEF-a u Hrvatskoj, Zagreb

Ana TOKIĆ

Pravni fakultet, Zagreb

UDK: $314.145(497.5): 37.04$

Izvorni znanstveni rad

Primljeno: 12. 10. 2009.

Cilj istraživanja bio je, na reprezentativnom uzorku, ispitati uvjerenja odraslih građana Hrvatske o poželjnom odnosu roditelja prema djeci mlađoj od 3 godine te provjeriti mogu li se ona predviđati na temeliu niza sociodemografskih varijabli. Rezultati su pokazali da je, uz najzastupljenije uvjerenje o važnosti roditeljske uključenosti, visoko zastupljeno i uvjerenje o važnosti poslušnosti i podređenosti djeteta odraslima. Manje su zastupliena uvjerenja o opravdanosti neodgovaranja na djetetov plač, uvjerenje o opravdanosti tjelesnoga kažnjavanja te uvjerenje o nepotrebnosti davanja objašnjenja zahtjeva i zabrana djetetu (indukcije). Spomenuta uvjerenja mogu se predviđati na temelju sociodemografskih obiliežja sudionika, kao što su, prije svega, stupanj obrazovanja, a zatim spol, dob i prihodi te broi članova kućanstva. Ovaj skup sociodemografskih prediktora najslabije predviđa uvjerenje o važnosti roditeljske uključenosti, a najbolje uvjerenje o nepotrebnosti indukcije. Kod slabije obrazovanih i starijih sudionika, s manjim prihodima, izraženija su uvjerenja o odnosu prema djetetu koja ne odgovaraju suvremenim znanstvenim spoznajama o primjerenoj roditeljskoj potpori ostvarenju djetetova razvojnog potencijala.

Ključne riječi: uvjerenja o roditeljskim postupcima, roditeljstvo, sociodemografska obiliežja, tjelesno kažnjavanje, rani razvoj djece

$\triangle \quad$ Ninoslava Pećnik, Pravni fakultet Sveučilišta u Zagrebu, Studijski centar socijalnog rada, Nazorova 51 , 10000 Zagreb, Hrvatska.

E-mail: ninapecnik@net.hr 


\section{Povezanost roditeljskih uvjerenja i roditeljskih postupaka}

Uvjerenja su znanja o svijetu, ljudima ili stvarima koja predstavljaju kognitivnu komponentu stava (Pennington, 2001.). Tako stav prema nekom ponašanju slijedi iz istaknutih uvjerenja osobe o tom ponašanju, njegovim posljedicama ili nekim drugim, pozitivno ili negativno vrednovanim, događajima do kojih dolazi izvođenjem toga ponašanja (Ajzen, 1985.). Ovaj rad bavi se uvjerenjima o poželjnim roditeljskim postupcima prema djeci mlađoj od 3 godine. U literaturi pojam "roditeljskih uvjerenja" pokriva širok raspon sadržaja - od vrlo specifičnih ideja o vremenskom rasporedu djetetova razvoja do mnogo općenitijih ciljeva socijalizacije. Jednu vrstu roditeljskih uvjerenja predstavljaju percepcije djeteta ili vlastitih roditeljskih sposobnosti (Okagaki i Bingham, 2005.). Kad se roditeljske percepcije odnose na uzroke određenih opaženih karakteristika ili ponašanja djeteta, radi se o roditeljskim atribucijama. Konačno, roditeljski ciljevi i očekivanja predstavljaju ishode kod djeteta koje se roditelji nadaju da će postići svojom interakcijom s djetetom. Suvremeno teorijsko stajalište jest da roditeljske socijalne kognicije ne djeluju kao zasebni utjecaji na roditeljsko ponašanje, već da su međusobno, a i s roditeljskim ponašanjem, povezane složenim vezama i moderacijskim efektima (Okagaki i Bingham, 2005.).

Roditeljska uvjerenja mogu nastati na temelju neposrednog iskustva ili se mogu formirati posredno, prihvaćanjem informacija iz vanjskih izvora (npr. rodbina, mediji). Ono što obilježava sva uvjerenja jest to da osoba "zna da je ono što smatra istinito ili vjerojatno istinito, a dokaz može i ne mora biti prisutan" (Sigel, 1985., 348), tj. sadržaj uvjerenja smatra se činjenicama ili istinom. Zbog tendencije da se uvjerenja međusobno sustavno povezuju i dopunjuju te jakog utjecaja kulture u tom procesu, Harkness i Super (1996.) sustav uvjerenja o ispravnom roditeljstvu nazivaju etnoteorije o roditeljstvu. Ove su etnoteorije proizvod specifične kulture, do njih se dolazi implicitno, bez znanstvenoga propitkivanja, a ljudi ih ne doživljavaju kao vjerovanja, nego se uzimaju "zdravo za gotovo".

Prevladavajuća roditeljska uvjerenja u nekom društvu važno je poznavati jer imaju niz funkcija. Ona motiviraju, oblikuju i pomažu organizirati roditeljska ponašanja (Bornstein i Cheah, 2006.). Još su LeVine i sur. (1988.) tvrdili da su u svim kulturama opći ciljevi koje roditelji imaju za svoju djecu slični, a da se odnose na (a) osiguravanje dječjega zdravlja i preživljavanja, (b) poučavanje vještinama koje će kasnije donijeti ekonomsku sigurnost djetetu te na (c) razvoj osobina djeteta 
DRUŠ. ISTRAŽ. ZAGREB GOD. 20 (2011), BR. 3 (113)

STR. $625-646$

PEĆNIK, N., RADOČAJ, T., TOKIĆ, A.:

UVJERENJA JAVNOSTI. koje su u skladu s lokalnim viđenjem vrlina. Ono što varira među kulturama jesu uvjerenja o tome koje su optimalne strategije koje dovode do ostvarenja tih ciljeva.

Objašnjenja odnosa između kognicija i ponašanja, proizašla iz međukulturne psihologije i antropologije (LeVine i sur., 1988.; Harkness i Super, 1996.), govore o hijerarhijskoj organizaciji kulturalnih uvjerenja i osobnoga ponašanja (od generalnih uvjerenja, preko specifičnih ciljeva do akcijskih skripti), što je u skladu sa socijalno-psihologijskim objašnjenjem veze između stava i ponašanja. Tako, prema teoriji planiranoga ponašanja (Ajzen, 1985.), kad osoba ima vremena za razmišljanje kako se ponašati, najbolji prediktor ponašanja jest namjera ponašanja, a najbolji prediktori namjere ponašanja jesu (a) stavovi prema specifičnom ponašanju, koji se, kao što je navedeno, formiraju iz istaknutih uvjerenja o tom ponašanju, (b) subjektivne norme, odnosno uvjerenja o tome kako će drugi ljudi do kojih im je stalo gledati na to ponašanje, i (c) percipirani stupanj kontrole nad ponašanjem, odnosno uvjerenja o lakoći izvođenja toga ponašanja.

Povezanost između roditeljskih uvjerenja i njihovih samoiskazanih ili opaženih ponašanja prema djetetu empirijski je dokazana. Primjerice, Hastings i Grusec (1998.) utvrdili su povezanost između roditeljskih kratkoročnih i dugoročnih ciljeva te roditeljskih ponašanja, kao što su tjelesno kažnjavanje, prisiljavanje, davanje objašnjenja, pregovaranje te pružanje emocionalne topline i prihvaćanja. Također je pronađeno da je stupanj uvjerenja majki u to da socijalna okolina može poboljšati djetetov razvoj pozitivno povezan s količinom i vrstom riječi koju majka rabi tijekom interakcije s djetetom (Donahue i sur., 1997.). Slično tome, utvrđena je srednje visoka povezanost uvjerenja majki o važnosti čitanja maloj djeci s kvalitetom interakcije majke i djeteta tijekom zajedničkoga čitanja (DeBaryshe, 1995.). Osim toga, rabeći opažane mjere osjetljiva ponašanja majki prema njihovoj tromjesečnoj dojenčadi (operacionalizirano kao brzo reagiranje na djetetov plač), Keller i suradnici (2003.) pronašli su da je osjetljivo ponašanje majki povezano s njihovim iskazanim uvjerenjima o (brzom) reagiranju na djetetov plač.

U literaturi su prisutne nejasnoće oko interpretacije smjera uzročno-posljedičnih veza između roditeljskih uvjerenja i ponašanja, jer se utjecaji mogu pretpostaviti s obje strane $(\mathrm{O}-$ kagaki i Bingham, 2005.). Slep i O'Leary (1998.) dali su doprinos rješavanju toga pitanja tako što su proveli eksperiment $u$ kojem su ispitivali utjecaje majčinih atribucija na njezino ponašanje, a koji je pokazao da je moguće mijenjati roditeljske kognicije $\mathrm{i}$ da te promjene dovode do promjena u ponašanju. 


\section{Važnost roditeljskih uvjerenja u razdoblju ranoga razvoja djeteta}

Posebno važnim čine se roditeljska uvjerenja o ponašanju prema djetetu u prvim godinama života, jer (u svim kulturama) djeca mogu razviti svoje prirođene potencijale samo $u$ interakciji s odraslim osobama, koje prepoznaju i primjereno odgovaraju na signale djeteta (Richter, 2004.). Podršku važnosti ranoga razdoblja daju i istraživanja na području neuroznanosti, jer pokazuju da se relativno trajna arhitektura moždanih putova formira u prvim godinama te kasnije utječe na način doživljavanja i reagiranja (Shonkoff i Phillips, 2000.). Upravo zbog toga istraživački interes usmjerili smo na uvjerenja o ispravnom odnosu prema najmlađoj djeci.

Uvjerenja o potrebama djeteta i o tome što čini dobro roditeljstvo u većoj ili manjoj mjeri odražavaju stručna znanja o navedenim pitanjima. U zapadnoj kulturi postoji slaganje stručnjaka o temeljnim razvojnim potrebama djeteta i primjerenim načinima kako da ih roditelj zadovolji (Daly, 2007.). Tako se najvažnijim odgovornostima roditelja smatraju (1) zadovoljenje temeljnih tjelesnih potreba djeteta, (2) briga o sigurnosti djeteta u domu i izvan njega, (3) pružanje emocionalne topline, (4) pružanje poticajnih uvjeta za učenje i razvoj, (5) usmjeravanje i postavljanje granica te (6) osiguravanje stabilnosti djetetove fizičke okoline i socijalnih veza.

Kada su u pitanju djeca najmlađe dobi, zadaće roditelja oko kojih se stručnjaci uglavnom slažu jesu zaštititi djecu, pomoći im da organiziraju osjećaje i reguliraju ponašanje te ohrabriti učenje i istraživanje okoline kako bi se povećalo njihovo znanje o vanjskom svijetu. Stoga bi roditeljstvo u prvim godinama djetetova života trebale odlikovati (1) autentičnost $\mathrm{u}$ ulozi roditelja i usmjerenost na dijete, (2) osjetljivost roditelja, odnosno sposobnost da se prepoznaju i interpretiraju signali djeteta te da se na njih odgovori brzo i na odgovarajući način, (3) vremenska usklađenost i repetitivna predvidljivost roditeljevoga ponašanja te (4) odgovarajuća kvaliteta emocionalne razmjene, koja uključuje izražavanje osjećaja, emocionalnu toplinu i prihvaćanje, nježnost i tješenje (Lalière i sur., 2005.).

\section{Odrednice roditeljskih uvjerenja}

Varijacije u roditeljskim uvjerenjima i ponašanjima posljedica su složenih utjecaja mnogih činitelja (Bronfenbrenner, 1999.). Najvažnije skupine antecedenata $u$ objašnjenju roditeljskih kognicija i postupaka uključuju biološka i psihološka obilježja roditelja, stvarna ili percipirana obilježja djeteta, kontekstualne utjecaje kao što su situacijski činitelji, obilježja obitelji, socioekonomski status i kultura (Bornstein i Cheah, 2006.). Roditeljstvo se odvija u višestrukim kontekstima, a načine na koje konteksti utječu na djetinjstvo i roditeljstvo Bornstein i Cheah (2006.) prikazuju kontekstualnim ekološkim modelom razvoja (Slika 1). 


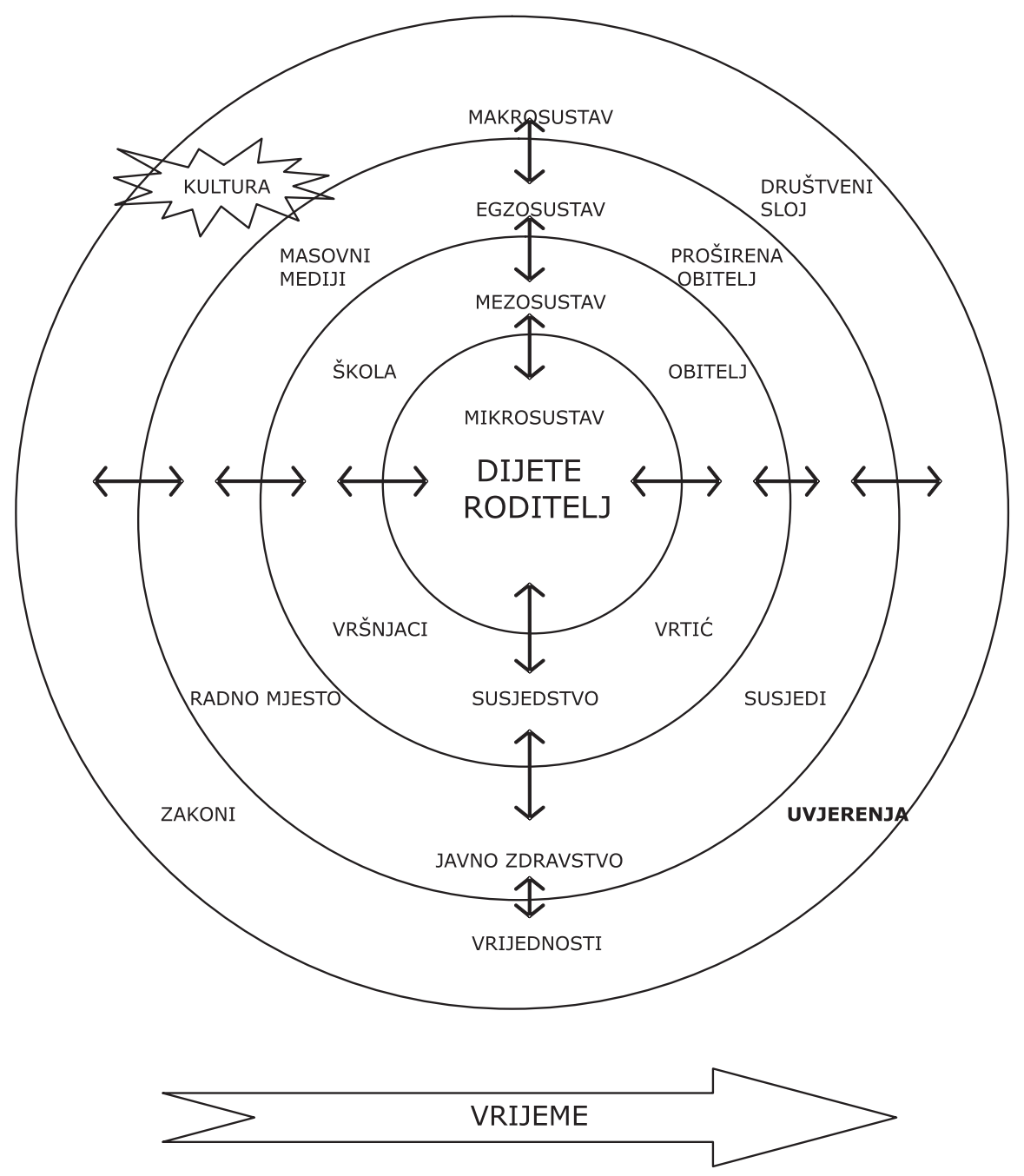

(1) SLIKA 1

Kontekstualni ekološki model razvoja djeteta i roditelia (Bornstein i Cheah, 2006.)
Prema viđenju razvoja prikazanom na Slici 1, makrosustav vrednota, uvjerenja, zakona i kulture podržava i potiče roditeljske kognicije i obrasce interakcija djeteta i roditelja. Na taj način širi društveni kontekst "propisuje" što će doživljavati djeca, odnosno kratkoročne i dugoročne roditeljske ciljeve te postupke kojima se roditelji koriste kako bi te ciljeve postigli. Model također pretpostavlja da će specifičnosti vezane uz različite podskupine unutar pojedine zemlje (npr. regije, etničke zajednice) "obojiti" njihova uvjerenja o podizanju djece i postupke prema djeci.

Oslanjajući se na ekološku perspektivu, Okagaki i Divecha (1993.) svrstali su činitelje koji utječu na roditeljska uvjerenja u činitelje izvan obiteljskog okruženja (kultura, socioekonomski status, posao, prijatelji i susjedi, savjeti stručnjaka) i činitelje unutar doma (obilježja roditelja, bračni odnosi, obi- 
DRUŠ. ISTRAŽ. ZAGREB GOD. 20 (2011),

BR. 3 (113),

STR. 625-646

PEĆNIIK, N., RADOČAJ, T., TOKIĆ, A.:

UVJERENJA JAVNOSTI... lježja djeteta - spol, dob, dostignuće). Od činitelja koji se očituju u raznolikosti uvjerenja unutar istoga kulturnog okruženja najviše su istraživana socioekonomska obilježja roditelja. Tako je pronađena povezanost nižega socioekonomskog statusa s autoritarnim i konformističkim uvjerenjima (Schaefer i Edgerton, 1985., prema Okagaki i Divecha, 1993.). Ninio (1979., prema Okagaki i Divecha, 1993.) nije utvrdio razliku u uvjerenjima o fizičkom razvoju male djece među majkama nižega i višega socioekonomskog statusa u Izraelu. Međutim, majke višega socioekonomskog statusa vjerovale su da djeca usvajaju kognitivne vještine ranije nego što su to mislile majke nižega statusa, što je pripisano posredujućem učinku informacija koje roditelji dobivaju o dječjem razvoju. Majke višega socioekonomskog statusa općenito imaju ranija očekivanja postizanja pojedinih stupnjeva kognitivnog razvoja dostignuća od majki nižega statusa (pregled u Okagaki i Bingham, 2005.). Obrazovanje roditelja također se pokazalo prediktivnim za njihova roditeljska uvjerenja. LeVine i suradnici (1988.) našli su razlike $\mathrm{u}$ roditeljskim etnoteorijama povezane $\mathrm{s}$ razlikama u obrazovanju i zaključili da školovanje podupire razvoj uvjerenja o dojenčadi kao partnerima u komunikaciji te da obrazovanije majke imaju ranija očekivanja od djece. Ta su uvjerenja bila povezana i s majčinim komunikacijskim ponašanjima i ishodima kod djece. Slično tome, istraživanje uvjerenja filipinskih majki o tome u kojoj će dobi njihova djeca steći određene kognitivne, psihosocijalne i psihomotoričke vještine pokazalo je da obrazovanije majke imaju viša očekivanja od djetetova kognitivnog i psihosocijalnog razvoja (Williams i sur., 2000.). Nadalje, Suizzo i suradnici (2008.) istraživali su roditeljska uvjerenja o specifičnim svakodnevnim postupcima s djecom od 1 do 3 godine. Uz iznimku sudionika azijskoga podrijetla, utvrđeno je da obrazovaniji roditelji smatraju uvjerenja koja se odnose na poslušnost $\mathrm{i}$ konformizam manje važnima u odnosu na roditelje nižega stupnja obrazovanja.

\section{Cilj istraživanja}

U Hrvatskoj su istraživanja roditeljskih uvjerenja malobrojna. Podaci prikupljeni od roditelja 1990. godine upućuju na to da se najvažnijim roditeljskim ciljevima smatraju djetetova samostalnost, a odmah iza toga poslušnost (Janković, 1998.). Podaci iz prvoga vala Europske studije vrednota pokazuju zastupljenost tradicionalnih, kolektivističkih, ali i modernih individualističkih odgojnih vrijednosti (Hoblaj i Črpić, 2000.). Na temelju navedenih rezultata smatra se da u našem društvu usporedno postoje tradicionalne odgojne vrijednosti i vrijednosti individualne samorealizacije djeteta te da su mogući njihovi sukobi i nedoumice u svijesti roditelja (Čudina-Obradović i Obradović, 2006.). 
DRUŠ. ISTRAŽ. ZAGREB GOD. 20 (2011), BR. 3 (113),

STR. $625-646$

PEĆNIK, N., RADOČAJ, T., TOKIĆ, A.:

UVJERENJA JAVNOSTI.
Dok se posljednjih godina $u$ razvojnoj psihologiji, ali i u obiteljskoj politici (Daly, 2007.), javljaju nove ideje o optimalnom roditeljskom ponašanju, pitanje je koliko se one odražavaju i na shvaćanja šire javnosti. Ovo istraživanje odgovara na potrebu daljnjeg upoznavanja uvjerenja o odnosu roditelja prema djeci u našem društvu.

Iako su u dosadašnjim istraživanjima ispitivani uglavnom roditelji, slijedom kontekstualnoga ekološkog razvojnog modela (Slika 1), ovo istraživanje zahvaća uvjerenja uzorka svih odraslih građana u Hrvatskoj. Naime, uz roditeljska uvjerenja, treba poznavati i što o tome koji su roditeljski postupci prihvatljivi ili poželjni misle druge osobe u društvu, koje također djeluju na interakciju roditelja i djece.

Cilj istraživanja bio je ispitati uvjerenja odraslih građana Republike Hrvatske o komunikaciji s djetetom i drugim aspektima odnosa prema djeci najmlađe dobi, o reagiranju na djetetov plač i tjelesno kažnjavanje te utvrditi mogu li se ona predviđati na temelju niza sociodemografskih varijabli.

\section{METODA}

\section{Sudionici i postupak}

Istraživanje je provedeno $\mathrm{u}$ okviru akcije Ureda UNICEF-a za Hrvatsku "Prve tri su najvažnije". Podaci su prikupljeni u studenom 2006. uz pomoć nezavisne agencije za istraživanje javnoga mišljenja PULS, telefonskom anketom na slučajnom, nacionalno reprezentativnom uzorku građana Republike $\mathrm{Hr}$ vatske starijih od 18 godina. Iako je uzorak slučajno odabran iz populacije kućanstava u Hrvatskoj koja posjeduju fiksnu telefonsku liniju (oko 85\%) te ograničen na građane koji su pristali sudjelovati $u$ istraživanju, on je naknadno ponderiran prema spolu, obrazovanju i regiji, u skladu s Popisom stanovništva iz 2001. godine.

Uzorak je dvostruko stratificiran prema regiji i veličini naselja te obuhvaća 600 sudionika, od čega $24,8 \%$ živi u Zagrebu i okolici, 17,9\% u Sjevernoj Hrvatskoj, 17,5\% u Slavoniji, 8,8\% u Lici i Banovini, 11,9\% u Hrvatskom primorju i Istri te $19,1 \%$ u Dalmaciji. Ukupno 23,3\% sudionika živi u gradovima većim od 100 tisuća stanovnika, 18,5\% u gradovima od 10 do 100 tisuća stanovnika, $15,9 \%$ u naseljima od 2 do 10 tisuća stanovnika, a oko $42,2 \%$ živi u naseljima s manje od 2000 stanovnika. Muškarci čine 47,3\% uzorka, a žene 52,7\%. Obrazovnu strukturu uzorka čini 3,9\% sudionika bez završene osnovne škole, $27 \%$ s osnovnoškolskim obrazovanjem, $54,8 \%$ sa srednjoškolskim obrazovanjem te $14,4 \%$ sa završenom višom školom ili fakultetom. Dob sudionika varira od 18 do 85 godina, a prevladavaju sudionici dobnih kategorija od 
46 do 60 godina (31,7\%) i od 31 do 45 godina (29\%). U ukupnom uzorku čak $78,2 \%$ sudionika izjavljuju da su roditelji, ali samo $15 \%$ sudionika živi u istom kućanstvu s djetetom mlađim od 5 godina.

\section{Instrumenti}

Upitnik uvjerenja o ispravnim roditeljskim postupcima prema djeci najmlađe dobi konstruiran je za potrebe ovog istraživanja, a sastoji se od niza tvrdnji koje predstavljaju uvjerenja o roditeljskim postupcima prema malom djetetu. Zadatak sudionika bio je za svaku tvrdnju procijeniti stupanj slaganja na skali od 1 (uopće se ne slažem) do 5 (potpuno se slažem). Tvrdnje su tematski organizirane $\mathrm{u}$ blokove. Prvi se odnosi na uvjerenja o ispravnom odnosu prema malom djetetu, a čini ga 16 čestica. Provedena faktorska analiza rezultirala je sa pet glavnih komponenti, čiji su karakteristični korijeni veći od 1, a koji objašnjavaju $55,9 \%$ ukupne varijance. Interpretacijom rezultata provedene faktorske analize definirano je pet podskala uvjerenja o odnosu roditelja prema malom djetetu: Uvjerenje o potrebi roditeljske uključenosti, Uvjerenje o poslušnosti i podređenosti djeteta odraslima, Uvjerenje o nepotrebnosti indukcije, Uvjerenje o štetnosti "prevelike" roditeljske uključenosti i Uvjerenje o potrebi uvažavanja djetetove osobnosti $i$ kompetencije. Ukupni rezultat na svakoj podskali definiran je kao prosjek odgovora na pripadajućim česticama, a veći rezultat na svakoj podskali upućuje na veću prisutnost određenog uvjerenja. Cestice koje definiraju prve tri podskale i procjene pouzdanosti kompozitnih mjera prikazane su u Tablici 1 . S obzirom na nezadovoljavajuću pouzdanost zadnjih dviju podskala $(\alpha=0,43 ; \alpha=0,37)$, one nisu upotrijebljene u daljnjoj analizi.

Drugi blok sadrži tvrdnje koje se tiču uvjerenja o reagiranju na plač maloga djeteta, a sastoji se od 5 čestica. Analiza glavnih komponenti rezultirala je dvjema glavnim komponentama kojima su karakteristični korijeni veći od 1, a koji objašnjavaju 58,1\% ukupne varijance. Interpretacijom rezultata faktorske analize definirane su dvije podskale uvjerenja o plaču maloga djeteta: Uvjerenje o opravdanosti neodgovaranja na djetetov plač i Uvjerenje o važnosti reagiranja na plač. Veći ukupni rezultat na podskalama upućuje na veću prisutnost uvjerenja $u$ nazivu (Tablica 1). S obzirom na nezadovoljavajuću pouzdanost druge podskale $(\alpha=0,25)$, ona nije uzeta $u$ daljnjoj analizi.

Treći blok tvrdnji odnosi se na uvjerenja o opravdanosti tjelesnoga kažnjavanja djeteta, a čini ga 6 čestica. Faktorska analiza rezultirala je generalnim faktorom koji objašnjava 55,4\% ukupne varijance. Veći ukupni rezultat upućuje na veću prisutnost uvjerenja o opravdanosti tjelesnoga kažnjavanja djeteta. Čestice koje tvore skalu te pripadajući Cronbachov alfa-koeficijent prikazani su u Tablici 1 . 
DRUŠ. ISTRAŽ. ZAGREB GOD. 20 (2011),

BR. 3 (113),

STR. $625-646$

PEĆNIK, N., RADOČAJ, T., TOKIĆ, A.:

UVJERENJA JAVNOSTI.
Sociodemografski upitnik sastoji se od niza pitanja o sociodemografskim karakteristikama sudionika, a to su redom: spol, dob, stupanj obrazovanja (bez osnovne škole, osnovna škola, srednja škola i viša škola ili fakultet), mjesečni prihod kućanstva u proteklom mjesecu (do 1000 kuna, 1001 - $4000 \mathrm{ku}$ na, 4001 - 5500 kuna, 5501 - 7000 kuna, 7001 - 8500 kuna, više od 8500 kuna), regija prebivališta (Zagreb i okolica, Sjeverna Hrvatska, Slavonija, Lika i Banovina, Hrvatsko primorje i Istra, Dalmacija), veličina naselja (više od 100000 stanovnika, 10000 - 100 000, 2000 - 10 000, manje od 2000 stanovnika), broj članova u kućanstvu, prisutnost djeteta mlađeg od 5 godina u kućanstvu (da, ne) i roditeljstvo (da, ne).

\section{REZULTATI I RASPRAVA}

\section{Zastuplienost uvjerenja o ispravnim roditeljskim postupcima prema djetetu najmlađe dobi}

Prvi problem ovog istraživanja bio je ispitati zastupljenost određenih uvjerenja o ispravnim roditeljskim postupcima prema djetetu do treće godine života na reprezentativnom uzorku odrasle populacije građana Hrvatske. U Tablici 1 prikazana je deskriptivna statistika i postotak odgovora na pojedine čestice iz Upitnika uvjerenja o roditeljskim postupcima prema malom djetetu. Čestice su grupirane u podskale koje su sastavljene prema rezultatima provedenih faktorskih analiza, a koje se odnose na uvjerenja o odnosu prema malom djetetu, reagiranju na plač i tjelesnom kažnjavanju. Iz tablice se može vidjeti koliko se sudionika slaže, odnosno ne slaže, s pojedinom tvrdnjom te aritmetička sredina za svaku tvrdnju dobivena na cijelom uzorku.

Najviši prosječni stupanj slaganja s pripadajućim tvrdnjama, kao i najmanja raspršenost odgovora sudionika, dobivena je za podskalu Uvjerenja o važnosti roditeljske uključenosti. To pokazuje da u hrvatskoj javnosti postoji generalni konsenzus oko roditeljskoga bavljenja djetetom i komunikacije s njime kao važnog aspekta roditeljstva, što potpuno odgovara znanstvenom stajalištu. Sudionici su bili manje suglasni oko ostalih uvjerenja, što je posebno izraženo kad je riječ o uvjerenju o nepotrebnosti indukcije te uvjerenju o opravdanosti neodgovaranja na dječji plač, gdje se sudionici raspodjeljuju na one koji jesu i one koji nisu tog uvjerenja.

Uz uvjerenje o važnosti roditeljske uključenosti, visoko je zastupljeno i uvjerenje o važnosti poslušnosti i podređenosti djeteta odraslima, s kojim se sudionici u prosjeku "uglavnom slažu". Dok je ovo uvjerenje karakteristično za tradicionalno, patrijarhalno viđenje odnosa djeteta i roditelja, suvremena psihologija naglašava razliku između poslušnosti i prihvaćanja vanjskih pravila ponašanja kao vlastitih (Grolnick i sur., 1997.). 
Uvjerenja o ispravnom odnosu prema malom djetetu

Uvjerenje o važnosti roditeljske uključenosti

$(\alpha=0,64 ; \mathrm{M}=4,7 ; \mathrm{SD}=0,47)$

Dijete brže uči i razvija se ako se netko s njim igra i razgovara.

Važno je s djetetom razgovarati od prvoga dana života.

Dijete treba pripremiti na neugodno iskustvo kao što su injekcija, cijepljenje i slično.

Važno je djetetu objasniti zašto nešto ne smije.

Malu djecu dobro je umiriti čitanjem slikovnice.

$M$ se ne slaže ne slaže

se slaže

Uvjerenje o poslušnosti i podređenosti djeteta odraslima

$(\alpha=0,67 ; \mathrm{M}=3,9 ; \mathrm{SD}=0,86)$

Kada odrasli razgovaraju, djeca ne smiju ometati razgovor.

Na javnim mjestima i u čekaonicama mala djeca trebaju

biti mirna i pristojna.

Važno je na vrijeme slomiti dječji prkos i tvrdoglavost,

jer drvo se svija dok je mlado.

Djecu treba naučiti da budu poslušna i da poštuju starije.

Uvjerenje o nepotrebnosti indukcije

$(\alpha=0,69 ; \mathrm{M}=2,4 ; \mathrm{SD}=1,16)$

Malom djetetu u dobi između jedne i tri godine nije potrebno

objašnjavati zašto nešto ne smije.

Ako djetetu predstoji neko neugodno iskustvo, najbolje je

ništa ne govoriti unaprijed, tako će neugoda brže proći.

Dijete mlađe od godine dana ništa ne razumije, pa mu

ne treba ništa objašnjavati.

$\begin{array}{rrrr}4,9 & 1 \% & 1 \% & 98 \% \\ 4,7 & 3 \% & 2 \% & 95 \% \\ & & & \\ 4,6 & 3 \% & 5 \% & 92 \% \\ 4,7 & 2 \% & 3 \% & 95 \% \\ 4,4 & 2 \% & 11 \% & 87 \%\end{array}$

$\begin{array}{llll}3,7 & 17 \% & 21 \% & 62 \%\end{array}$

$\begin{array}{llll}3,8 & 14 \% & 19 \% & 67 \%\end{array}$

$\begin{array}{llll}3,5 & 27 \% & 19 \% & 54 \%\end{array}$

$4,6 \quad 3 \% \quad 4 \% \quad 93 \%$

Uvjerenja o opravdanosti neodgovaranja na djetetov plač $(\alpha=0,64 ; \mathrm{M}=2,6 ; \mathrm{SD}=1,13)$

Mala djeca često plaču bez razloga, pa je najbolje ne reagirati.

Ako se majka odazove svaki put kad dijete plače,

time će razmaziti dijete.

Dobro je ponekad pustiti dijete da dugo plače jer tako jača pluća. 2,2

$\begin{array}{rrrr}2,2 & 67 \% & 9 \% & 24 \% \\ 3,0 & 38 \% & 22 \% & 40 \% \\ 2,1 & 72 \% & 9 \% & 19 \%\end{array}$

Uvjerenja o opravdanosti tjelesnoga kažnjavanja

$(\alpha=0,84 ; \mathrm{M}=2,5 ; \mathrm{SD}=1,06)$

$\begin{array}{lllll}\text { Dijete treba nekada dobiti dobre batine kako bi zapamtilo lekciju. } 1,8 \quad 78 \% & 10 \% & 12 \%\end{array}$

Za pravilan odgoj djece nužno je ponekad udariti dijete $\quad-2,5-52 \%$

$\begin{array}{llll}\text { Opravdano je udariti dijete kako bi zapamtilo što ne smije raditi. } 2,3 & 61 \% & 15 \% & 24 \%\end{array}$

Opravdano je udarati dijete kada divlja i pravi scenu bez razloga. $2,5 \quad 58 \% \quad 12 \% \quad 30 \%$

$\begin{array}{lllll}\begin{array}{l}\text { Nekad je u redu udariti dijete ako dovodi svoj život u opasnost, } \\ \text { primjerice kad se penje na prozor ili istrči na ulicu. }\end{array} & 3,3 & 33 \% & 17 \% & 50 \%\end{array}$

Opravdano je udariti dijete ako je ono udarilo nekoga drugog,

da mu pokažemo kako to boli.

$2,5 \quad 56 \% \quad 15 \% \quad 29 \%$

* Uzorak je ponderiran prema spolu, obrazovanju i regiji.

(1) TABLICA 1

Deskriptivna analiza čestica Upitnika uvjerenja o roditeljskim postupcima prema malom dietetu $(\mathrm{N}=600)^{*}$
Najniži prosječni stupanj slaganja s pripadajućim tvrdnjama utvrđen je uz uvjerenje o nepotrebnosti indukcije (davanja objašnjenja zahtjeva i pravila). Iako sudionici uglavnom odbacuju to uvjerenje ili su oko toga neopredijeljeni, ipak se svaki četvrti slaže s tim da "Malom djetetu u dobi između jedne i tri godine nije potrebno objašnjavati zašto nešto ne smije". Ovakvo je mišljenje sasvim suprotno suvremenim 
DRUŠ. ISTRAŽ. ZAGREB GOD. 20 (2011), BR. 3 (113)

STR. $625-646$

PEĆNIK, N., RADOČAJ, T., TOKIĆ, A.:

UVJERENJA JAVNOSTI. znanstvenim spoznajama o važnosti objašnjavanja očekivanja i pravila u procesu internalizacije prihvatljiva ponašanja (Grolnick i sur., 1997.). Općenito, usporede li se prevladavajuća uvjerenja sudionika o ispravnom odnosu prema malom djetetu sa znanstvenim spoznajama o obilježjima odgovarajuće roditeljske skrbi (npr. Daly, 2007.), zamjećuje se veća usklađenost oko vrednovanja uključenosti, pružanja pažnje i stimulacije, nego oko poštovanja djeteta kao osobe i podupiranja djetetove autonomije. Navedeno najbolje ilustrira relativno veliko slaganje s tvrdnjom "Važno je na vrijeme slomiti dječji prkos i tvrdoglavost jer drvo se svija dok je mlado" (54\% sudionika se potpuno ili uglavnom slaže), kao i relativno velik broj neopredijeljenih ispitanika uz tu tvrdnju. Shvaćanje djeteta mijenjalo se kroz povijest, od gledanja na dijete kao na pasivan objekt koji utjecaji okoline oblikuju (tzv. model modeliranja gline), odnosno obuzdavaju djetetove antisocijalne tendencije (tzv. model konflikta), do suvremenoga shvaćanja djeteta kao aktivnoga sudionika u procesu vlastita razvoja (tzv. model uzajamnosti) (Schaffer, 1996.; Pećnik, 2008.a). Nove spoznaje razvojne psihologije o sposobnostima i prosocijalnoj orijentaciji dojenčadi (Schaffer, 1996.), spoznaje tzv. "nove sociologije djetinjstva" (Morrow, 2003.) te socijalne politike koje promiču prava djeteta predstavljaju širi društveni kontekst koji teorijski podupire viđenje djeteta i roditelja u skladu s modelom uzajamnosti i relacijskom određenju socijalizacije (Pećnik, 2008.a). Međutim, rezultati našeg istraživanja, posebno uz prethodno spomenutu tvrdnju, kao i uz tvrdnje koje zahvaćaju uvjerenja o opravdanosti neodgovaranja na djetetov plač te tjelesnoga kažnjavanja, upućuju na značajan udio građana Hrvatske kod kojih su prisutna uvjerenja karakteristična za modele koji su povijesno prethodili suvremenom modelu uzajamnosti, a danas su uglavnom napušteni.

Prosječan rezultat na podskali Uvjerenje o opravdanosti neodgovaranja na dječji plač upućuje na neopredijeljenost sudionika oko "ispravnih" roditeljskih reakcija na djetetov plač. Dok oko polovice ispitanih izražava neslaganje s ovim uvjerenjem, relativno je velik udio onih koji vjeruju da "mala djeca plaču bez razloga, pa je najbolje ne reagirati" ( $30 \%$ sudionika potpuno se ili uglavnom slaže), da "će majka razmaziti dijete ako se odazove svaki put kad dijete plače" (36\% sudionika potpuno se ili uglavnom slaže), pa čak i da je "dobro ponekad pustiti dijete da dugo plače jer tako jača pluća" (22\% sudionika potpuno se ili uglavnom slaže). Veliko raspršenje uvjerenja o reagiranju na plač dobiveno u našem istraživanju u skladu je i s odgovorima britanskih roditelja da dobivaju razne poruke od stručnjaka i okoline o tome kako se nositi s problemima plača kod dojenčadi (St James-Roberts, 2007.). 
DRUŠ. ISTRAŽ. ZAGREB GOD. 20 (2011),

BR. 3 (113),

STR. 625-646

PEĆNIK, N., RADOČAJ, T. TOKIĆ, A.:

UVJERENJA JAVNOSTI..
Prisutan je sukob između pristupa koji se temelji na brzom zadovoljavanju iskazanih ili pretpostavljenih potreba dojenčeta i pristupa koji se temelji na strukturiranijim oblicima skrbi (strukturirane rutine kao što je hranjenje i stavljanje dojenčeta na spavanje $u$ isto vrijeme - bez obzira na plač). Međutim, opća tendencija brzoga reagiranja na djetetove signale ključna je sastavnica roditeljske osjetljivosti te pravodobnog $\mathrm{i}$ primjerenog odgovaranja na djetetove poruke (responzivnosti). Kada su roditelji osjetljivi, dijete uči da može komunicirati sa svojom okolinom, a roditelji uspijevaju zadovoljiti potrebe djeteta i olakšati uspostavljanje veze između ponašanja djeteta i utjecaja na okolinu (Lalière i sur., 2005.). Davidov i Grusec (2006.) proučavali su roditeljske reakcije kada je dijete uznemireno ili pod stresom, jer ih smatraju ključnim za razvoj sigurne privrženosti i samoregulaciju stresa. Oni razlikuju negativne i neosjetljive reakcije, kao što je neprijateljstvo, neobaziranje ili uzrujavanje, od pozitivnih i osjetljivih reakcija, kao što je tješenje i pružanje pomoći. Neuroznanost daje dodatne dokaze o utjecaju stresa u najranijoj dobi. Dok male količine stresa (umjereno intenzivno i povremeno suočavanje s nepoznatim i frustracijom) mogu djelovati stimulirajuće na razvoj, stres postaje toksičan za mozak u razvoju kada su posrijedi snažne i produžene reakcije, a bez ublažujuće utjehe odrasle osobe (National Scientific Council on the Developing Child, 2005.).

Tjelesno kažnjavanje definira se kao svako kažnjavanje u kojemu je upotrijebljena fizička sila i kojemu je namjera nanijeti određeni stupanj boli ili nelagode, bez obzira na to koliko blaga bila (Lee, 2008.). Prosječan rezultat na podskali Uvjerenja o opravdanosti tjelesnoga kažnjavanja odgovara vrijednosti odgovora "niti se slažem, niti se ne slažem", što upućuje na odbacivanje, ali i na prisutnost ovog uvjerenja u hrvatskoj javnosti, unatoč zakonskoj zabrani tjelesnoga kažnjavanja djece (Obiteljski zakon, 1998.). Tek jedna trećina sudionika ne vjeruje da je "nekad u redu udariti dijete ako dovodi svoj život $\mathrm{u}$ opasnost, primjerice kad se penje na prozor ili istrči na ulicu", dok se s ovom tvrdnjom slaže polovica sudionika. Ovako veliko prihvaćanje ideje o opravdanosti tjelesnoga kažnjavanja u situaciji kad je dijete u životnoj opasnosti upućuje na manjak znanja o tome da se uspostavljanje strukture prihvatljiva ponašanja kod male djece provodi $u$ prvom redu kroz osiguranje okoline, nadziranje djetetovih aktivnosti te poučavanjem pravilima sigurna ponašanja (Durrant, 2007.). Sudeći prema rezultatima, ne samo da izostaje "nulta tolerancija" na fizičko nasilje prema djeci nego četvrtina uzorka smatra da je tjelesno kažnjavanje nužan dio odgoja, na što upućuju odgovori uz tvrdnju "Za pravilan odgoj djece neophodno je po- 
DRUŠ. ISTRAŽ. ZAGREB GOD. 20 (2011), BR. 3 (113)

STR. $625-646$

PEĆNIIK, N., RADOČAJ, T., TOKIĆ, A.:

UVJERENJA JAVNOSTI. nekad udariti dijete" (27\% sudionika potpuno se ili uglavnom slaže). Tolerantni stavovi prema upotrebi tjelesnoga kažnjavanja, odnosno slaganje s tjelesnim kažnjavanjem i njegovo opravdavanje, značajan su činitelj rizika za takvo ponašanje (Aetah i Durrant, 2005.), koje je, uz to što krši djetetova ljudska prava, povezano i s nizom nepovoljnih razvojnih ishoda na planu ponašanja i doživljavanja djeteta te odnosa s roditeljem. Na njih upućuju rezultati novije metaanalize 88 istraživanja korelata tjelesne kažnjavanosti (Gershoff, 2002.), koja uz veću neposrednu poslušnost (utvrđenu u 3 od 5 analiziranih istraživanja) kod djece koja doživljavaju više tjelesnoga kažnjavanja pronalazi i veću agresivnost (u 27 od 27 istraživanja), više društveno neprihvatljivoga ponašanja (11 od 12 istraživanja), slabiju internalizaciju moralnih standarda (13 od 15 istraživanja), slabije mentalno zdravlje djeteta (12 od 12 istraživanja), slabiju kvalitetu odnosa roditelja i djeteta (13 od 13 istraživanja) te povećani rizik za tjelesnu ozljedu djeteta (10 od 10 istraživanja).

Ukupno uzevši, u nekim rezultatima prikazanima u Tablici 1 (npr. prihvaćenost ideja o "slamanju dječjega prkosa", izazivanju "razmaženosti", nepotrebnosti davanja objašnjenja, opravdanosti neodazivanja na djetetov plač i tjelesnoga kažnjavanja) mogu se prepoznati potencijalno štetne i zastarjele ideje o ispravnim roditeljskim postupcima prema najmlađoj djeci kod dijela sudionika istraživanja. Otvoreno je pitanje $u$ kojoj se mjeri ova uvjerenja odražavaju na ponašanje prema djeci. Neki noviji nalazi o ponašanju roditelja kod nas dodatan su razlog za zabrinutost oko učinka uvjerenja o odgovaranju na djetetov plač i o tjelesnom kažnjavanju na život djece najmlađe dobi. Tako je istraživanje s roditeljima djece između 1 i 12 mjeseci $(N=1363)$ pokazalo da njih $45,3 \%$, rjeđe ili češće, pušta dijete da plače jer ga ne želi razmaziti (Pećnik, 2008.b). Pritom je među 271 roditeljem novorođenčadi od mjesec dana svaki peti roditelj odgovorio da to čini ponekad, često ili uvijek, a svaki četvrti da to čini rijetko. U istom je istraživanju od 280 roditelja djece od 12 mjeseci tjelesno kažnjavanje udarcem po stražnjici u proteklih 7 dana upotrijebila gotovo trećina roditelja $(30,1 \%)$, a udarcem po ruci četvrtina (26\%). Među nešto starijom djecom još je više tjelesno kažnjavanih. Primjerice, među majkama šestogodišnjaka samo ih četvrtina izjavljuje da nije nikad udarila dijete (Delale i Pećnik, 2010.).

Daljnja analiza podataka odnosila se na provjeru povezanosti između pojedinih uvjerenja o ispravnom roditeljskom postupanju s malom djecom. Podaci u korelacijskoj matrici (Tablica 2) upućuju na to da su ispitivana uvjerenja međusobno slabo do umjereno povezana. Tako sudionici koji tjele- 
DRUŠ. ISTRAŽ. ZAGREB

GOD. 20 (2011)

BR. $3(113)$

STR. $625-646$

PEĆNIK, N., RADOČAJ, T., TOKIĆ, A.:

UVJERENJA JAVNOSTL. sno kažnjavanje djeteta smatraju prikladnim postupkom ujedno u većoj mjeri smatraju da je opravdano ne reagirati na dječji plač $\left(r=0,321^{* *}\right)$, indukciju smatraju nepotrebnom $\left(r=0,437^{* *}\right)$ te drže da dijete treba biti poslušno i podređeno odraslima $\left(\mathrm{r}=0,458^{* *}\right)$.

\begin{tabular}{|c|c|c|c|c|c|}
\hline & VRU & PDO & NI & NOP & OTK \\
\hline Uvjerenje o važnosti roditeljske uključenosti (VRU) & 1 & $0,144^{* *}$ & $-0,092^{*}$ & $-0,134^{* *}$ & $-0,015$ \\
\hline $\begin{array}{l}\text { Uvjerenje o poslušnosti i podređenosti } \\
\text { djeteta odraslima (PDO) }\end{array}$ & & 1 & $0,374^{* *}$ & $0,321^{* *}$ & $0,458^{* *}$ \\
\hline Uvjerenje o nepotrebnosti indukcije (NI) & & & 1 & $0,379 * *$ & $0,437^{* *}$ \\
\hline $\begin{array}{l}\text { Uvjerenje o opravdanosti neodgovaranja } \\
\text { na dječji plač (NOP) } \\
\text { Uvjerenje o opravdanosti tjelesnoga kažnjavanja (O }\end{array}$ & & & & 1 & $\begin{array}{l}0,321^{* *} \\
1\end{array}$ \\
\hline
\end{tabular}

${ }^{* *} \mathrm{p}<0,01 ;{ }^{*} \mathrm{p}<0,05$

(1) TABLICA 2

Matrica interkorelacija među uvjerenjima o roditeljskim postupcima prema malom dietetu $(\mathrm{N}=600)$
S druge strane, osobe s izraženim uvjerenjem u važnost roditeljske uključenosti $\mathrm{u}$ odnos $\mathrm{s}$ djetetom nešto su sklonije indukciji $\left(\mathrm{r}=-0,092^{* *}\right)$, a manje sklone ignoriranju djetetova plača $\left(\mathrm{r}=-0,134^{* *}\right)$. Utvrđene interkorelacije govore u prilog postojanju širih kategorija međusobno podupirućih uvjerenja, što odgovara pojmu roditeljskih etnoteorija (Harkness i Super, 1996.), odnosno kulturno oblikovanih sustava uvjerenja.

\section{Predviđanje uvjerenja o roditeljskim postupcima prema malom djetetu na temelju sociodemografskih obilježja}

Kako bi se odgovorilo na pitanje mogu li se i u kojoj mjeri uvjerenja o ispravnim roditeljskim postupcima prema malom djetetu objasniti na temelju sociodemografskih obilježja sudionika, provedeno je 5 regresijskih analiza za kriterije pojedinih uvjerenja sa sljedećim varijablama kao prediktorima: spol, dob, stupanj obrazovanja, mjesečni prihod kućanstva, regija prebivališta, veličina naselja, broj članova u kućanstvu, prisutnost djeteta mlađeg od 5 godina u kućanstvu i roditeljstvo (Tablica 3). Pritom je kvalitativna prediktorska varijabla regija prebivališta transformirana u 5 "tobožnjih" dihotomnih kvantitativnih varijabli (Milas, 2005.): Zagreb i okolica, Sjeverna Hrvatska, Slavonija, Lika i Banovina, Hrvatsko primorje i Istra, Dalmacija. Rezultati provedenih regresijskih analiza sumirani su u Tablici 3. Svi regresijski modeli kreirani na temelju nabrojenih prediktora pokazali su se statistički značajnima, a postotak objašnjene varijance kriterija varira $u$ rasponu od 2,7\% do 19,6\%, ovisno o kriterijskoj varijabli. Tako je ovaj skup sociodemografskih prediktora najmanje uspješan kad se njime predviđa uvjerenje o važnosti roditeljske 
DRUŠ. ISTRAŽ. ZAGREB GOD. 20 (2011), BR. 3 (113)

STR. $625-646$

PEĆNIK, N., RADOČAJ, T., TOKIĆ, A.:

UVJERENJA JAVNOSTI.

varijabilitetom ove kriterijske varijable, koji može biti rezultat stvarne uniformnosti roditeljskih uvjerenja, ali i očitih socijalno poželjnih odgovora. Isti skup prediktora najuspješniji je u predviđanju uvjerenja o nepotrebnosti indukcije.

U Tablici 3 prikazani su samo regresijski koeficijenti onih prediktorskih varijabli koje značajno doprinose objašnjenju varijance u kriteriju. Tako se kod predviđanja uvjerenja o važnosti roditeljske uključenosti samo spol ispitanika pokazao kao značajan prediktor, a uspješno je objašnjeno tek $2,7 \%$ varijance. Kod žena je ovo uvjerenje prisutno u nešto većoj mjeri nego kod muškaraca.

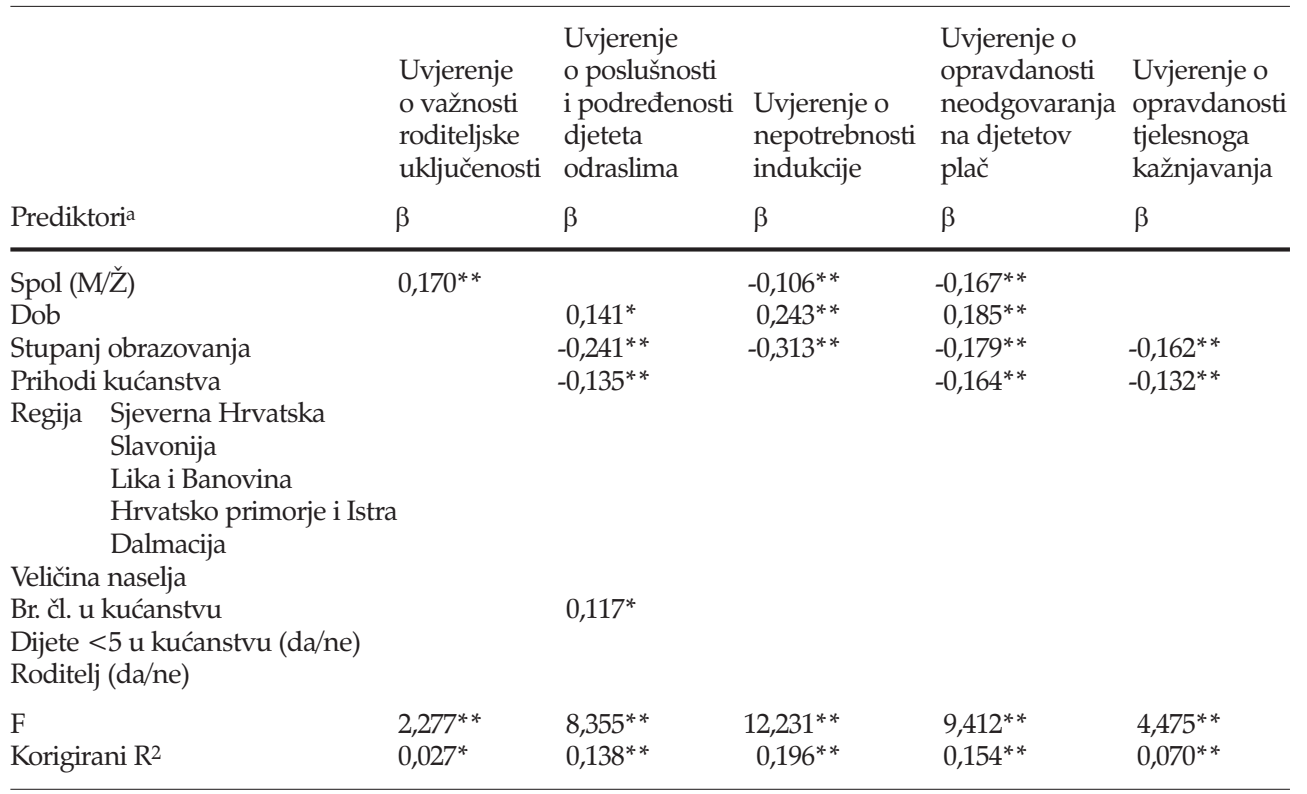

${ }^{*} \mathrm{p}<0,05 ; * \mathrm{p}<0,01$

aViši rezultat znači ženski spol, višu dob, stupanj obrazovanja i prihode te pripadnost većem kućanstvu.

i) TABLICA 3

Rezultati regresijskih analiza u kojima se predviđaju uvierenja ispitanika o ispravnim roditeliskim postupcima prema malom dietetu $(\mathrm{N}=600)$
Prilikom predviđanja uvjerenja o poslušnosti i podređenosti djeteta odraslima objašnjeno je ukupno 13,8\% varijance $\mathrm{u}$ kriteriju, $\mathrm{i}$ to sljedećim prediktorskim varijablama: dob, stupanj obrazovanja i prihodi kućanstva ispitanika te broj članova u kućanstvu. Stariji i manje obrazovani ispitanici imaju nešto izraženije ovo uvjerenje nego mlađi i obrazovaniji. Ovo je uvjerenje izraženije i kod ispitanika s većim brojem članova u kućanstvu te s nižim mjesečnim prihodom kućanstva.

Ukupno 19,6\% uvjerenja o nepotrebnosti indukcije objašnjeno je skupom prediktora, a statistički značajnima pokazali su se spol, dob i stupanj obrazovanja. Kod muškaraca, starijih i ispitanika nižega stupnja obrazovanja ovo je uvjerenje nešto izraženije $u$ odnosu na žene, mlađe ispitanike $\mathrm{i}$ ispitanike s višim završenim stupnjem obrazovanja. 
DRUŠ. ISTRAŽ. ZAGREB GOD. 20 (2011),

BR. $3(113)$

STR. 625-646

PEĆNIK, N., RADOČAJ, T. TOKIĆ, A.:

UVJERENJA JAVNOSTI...
Prilikom predviđanja uvjerenja o opravdanosti neodgovaranja na dječji plač objašnjeno je ukupno $15,4 \%$ varijance u kriteriju, a beta-koeficijenti sljedećih prediktora dostigli su statističku značajnost: spol, dob, stupanj obrazovanja i prihodi kućanstva. Kod muškaraca, starijih, niže obrazovanih i ispitanika čija kućanstva manje privređuju ovo je uvjerenje nešto izraženije u odnosu na žene, mlađe, obrazovanije ispitanike te ispitanike čija kućanstva mjesečno privređuju više.

Ukupno 7\% uvjerenja o opravdanosti tjelesnoga kažnjavanja djeteta objašnjeno je navedenim skupom sociodemografskih obilježja, a statistički značajnim prediktorima pokazali su se stupanj obrazovanja i prihodi kućanstva. Kod osoba nižega stupnja obrazovanja te osoba s nižim prihodima kućanstva ovo je uvjerenje nešto izraženije u odnosu na osobe $s$ višim završenim stupnjem obrazovanja te višim prihodima kućanstva.

Regija, veličina naselja, roditeljstvo te prisutnost djeteta mlađeg od 5 godina u kućanstvu nisu se pokazali prediktivnima u predviđanju ni jednoga tipa uvjerenja. Međutim, važno je napomenuti da to ne znači nužno da su ove prediktorske varijable $\mathrm{u}$ nultoj korelaciji sa zadanim kriterijima, nego da u regresijskom modelu (u kontekstu ostalih prediktorskih varijabli) nisu došle do izražaja, odnosno nisu dale jedinstveni nezavisni doprinos objašnjenju kriterijskih varijabli.

Ukupno gledajući, rezultati pokazuju da se uvjerenja građana o ispravnim roditeljskim postupcima prema djeci najmlađe dobi mogu predviđati na temelju njihovih sociodemografskih obilježja. U uvjerenjima o nepotrebnosti indukcije, opravdanosti neodgovaranja na plač i podređenosti djeteta odraslima udjeli objašnjene varijance nešto su veći nego za uvjerenja o važnosti roditeljske uključenosti i opravdanosti tjelesnoga kažnjavanja. Relativno malen udio varijance koja je objašnjena sociodemografskim obilježjima u najvećoj je mjeri posljedica mnogobrojnosti činitelja koji određuju roditeljska uvjerenja - od utjecaja socioekonomskoga statusa i podrške socijalne okoline do činitelja vezanih uz psihološka obilježja roditelja i obilježja djeteta (Okagaki i Divecha, 1993.). Od ispitivanih, najznačajnijim prediktorom pokazao se stupanj obrazovanja, pa dob, spol i prihodi kućanstva.

Povezanost obrazovanja i roditeljskih uvjerenja utvrđena je i u drugim istraživanjima (Le Vine i sur., 1988.). Kako je dostupnost informacija jedan od osnovnih procesa kojim okolina posredno djeluje na uvjerenja ljudi (Okagaki i Divecha, 1993.), pretpostavljamo da nove spoznaje na kojima mogu utemeljiti svoja uvjerenja lakše dopiru upravo do nekih dijelova stanovništva. Obrazovanijim i mlađim pojedincima dostupniji su savjeti stručnjaka uz pomoć knjiga ili interneta, 
DRUŠ. ISTRAŽ. ZAGREB GOD. 20 (2011), BR. 3 (113)

STR. $625-646$

PEĆNIK, N., RADOČAJ, T., TOKIĆ, A.:

UVJERENJA JAVNOSTI. ali i ideje iz poslovne okoline ili neformalnih socijalnih mreža. No čini se da su oni zainteresirani i za više, jer veću dostupnost točnih i međusobno usklađenih stručnih informacija o njezi i odgoju djeteta ističu kao jednu od glavnih potreba roditelja u skrbi za dijete u prvoj godini života (Pećnik, 2008.b).

Roditeljska uvjerenja oblikuju se pod utjecajem raznih izvora informacija do kojih roditelj drži (Bornstein i Cheah, 2006.). Primjerice, pokazalo se da roditelji tromjesečne djece $(\mathrm{N}=283)$ najviše savjeta o njezi djeteta dobivaju od baka $(42 \%)$, zatim od pedijatra / liječnika (31\%), prijateljica (21\%), a u toj dobi tek $6-8 \%$ roditelja traži odgovore u knjigama i na internetu (Pećnik, 2008.b). Stoga je u planiranju informativnih kampanja nužno uzeti u obzir i osobe koje neposredno savjetuju mlade roditelje, jer njihovi savjeti, kako sugeriraju nalazi ovog istraživanja, zbog nižeg obrazovanja i/ili starije dobi mogu biti neusklađeni sa suvremenim stavom struke.

Rezultati upućuju i na određene spolne razlike u uvjerenjima o ispravnim roditeljskim postupcima. U odnosu na muške ispitanike, žene u većoj mjeri gaje uvjerenja o potrebi roditeljske uključenosti, a manje su sklone vjerovati da na taj način mogu "razmaziti" dijete, rjeđe vjeruju da su postupci indukcije nepotrebni te nešto rjeđe izjavljuju da je opravdano ne odgovoriti na dječji plač. To je u skladu sa stereotipnom ulogom majke te nalazima da su majke u odnosu s djecom općenito responzivnije i uključenije nego očevi (Čudina-Obradović i Obradović, 2006.).

\section{Završna rasprava}

Poznavanje zastupljenosti određenih uvjerenja o odnosu roditelja prema najmlađoj djeci u populaciji, kao i njihovih mogućih uzroka, važno je kako bi se na pogrešna ili štetna uvjerenja moglo utjecati. Riječ je o uvjerenjima koja mogu poslužiti kao motivacija ili opravdanje neuvažavajućega, neosjetljivoga i nasilnoga ponašanja prema djeci te pružanje podrške ili nametanje socijalnoga pritiska drugima da se tako ponašaju. Postojanje povezanosti roditeljskih uvjerenja s roditeljskim ponašanjima te roditeljskih ponašanja s razvojnim ishodima kod djece sugerira mogućnost da roditeljska uvjerenja o ispravnom postupanju prema djetetu donekle doprinose reprodukciji socijalnih nejednakosti transgeneracijskim prijenosom istih uvjerenja. Ovoj pretpostavci ide u prilog i nalaz da su kod osoba s nižim prihodima u kućanstvu uvjerenja o ispravnim postupcima prema djeci suprotna onima koja podupiru ostvarenje djetetova razvojnog potencijala (Tablica 3).

Ovo je istraživanje pionirski pokušaj utvrđivanja domi- 
DRUŠ. ISTRAŽ. ZAGREB GOD. 20 (2011), BR. $3(113)$

STR. 625-646

PEĆNIK, N., RADOČAJ, T. TOKIĆ, A.:

UVJERENJA JAVNOSTI.. ma malom djetetu u Hrvatskoj. Utvrđen je i skup sociodemografskih varijabli na temelju kojih se $\mathrm{u}$ određenoj mjeri može predviđati sadržaj uvjerenja, ali je velik dio varijabiliteta još ostao neobjašnjen, što ne začuđuje s obzirom na široku lepezu mogućih utjecaja na ljudsku kogniciju. Praktična svrha istraživanja uvjerenja o odnosu prema djeci počiva na pretpostavci da se promjena roditeljskoga ponašanja može ostvariti upravo utjecajem na roditeljske kognicije i promjenom roditeljskih kognicija. Kao što je već istaknuto, sustavi uvjerenja o ispravnom načinu ponašanja ili razmišljanja o malom djetetu često su implicitni i nerijetko su u neskladu sa znanstvenim spoznajama. Zbog toga je na području promicanja ranoga razvoja djece od neizmjerne važnosti ciljanim edukativnim kampanjama poticati kritičko propitkivanje stečenih uvjerenja, popularizirati znanost i stvarati javno mišljenje usklađeno sa znanstvenim i društvenim dostignućima.

Ipak, neka metodološka ograničenja istraživanja donekle umanjuju snagu njegovih nalaza. Metoda prikupljanja podataka rezultirala je pristranim uzorkom stanovnika koji imaju telefon i bili su voljni sudjelovati. Ovaj smo nedostatak većim dijelom uspjeli umanjiti postupkom ponderiranja prema spolu, dobi i regiji u skladu s popisom stanovništva iz 2001. Kako su podaci dobiveni samoiskazom, otvoreno je pitanje koliko su odgovori iskreni, odnosno koliko su pod utjecajem socijalne poželjnosti. Korelacijska priroda istraživanja ne omogućuje zaključivanje o uzročno-posljedičnim vezama između sociodemografskih prediktora i ispitivanih kognicija. Provedeno istraživanje upućuje na potrebu provođenja daljnjih, metodološki usavršenijih istraživanja uvjerenja o ispravnom odnosu prema najmlađoj djeci i njihovih determinanti, ali i na potrebu da dobivene znanstvene spoznaje dopru do šire javnosti i, ondje gdje je potrebno, potaknu pozitivne promjene prema najmlađoj djeci.

\section{LITERATURA}

Aetah, C. A. i Durrant, J. E. (2005.), Maternal Use of Physical Punishment in Response to Child Misbehavior: Implications for Child Abuse Prevention. Child Abuse and Neglect, 29 (2): 169-185.

Ajzen, I. (1985.), From Intentions to Actions: A Theory of Planned Behavior. U: J. Kuhl i J. Beckmann (ur.), Action-Control: From Cognition to Behavior (str. 11-39), Heidelberg: Springer-Verlag.

Bornstein, M. H. i Cheah, C. S. L. (2006.), The Place of 'Culture and Parenting' in the Ecological Contextual Perspective on Developmental Science. U: K. H. Rubin i O. B. Chung (ur.), Parenting Beliefs, Behaviors and Parent-Child Relations: A Cross-Cultural Perspective (str. 3-33), New York: Taylor and Francis Group.

Bronfenbrenner, U. (1999.), Environments in Developmental Perspective: Theoretical and Operational Models. U: L. S. Friedman i T. D. 
DRUŠ. ISTRAŽ. ZAGREB GOD. 20 (2011), BR. 3 (113)

STR. $625-646$

PEĆNIIK, N., RADOČAJ, T., TOKIĆ, A.:

UVJERENJA JAVNOSTI.
Wachs (ur.), Measuring Environment across the Lifespan: Emerging Methods and Concepts (str. 3-28), Washington, DC: American Psychological Association Press.

Čudina-Obradović, M. i Obradović, J. (2006.), Psihologija braka i obitelji, Zagreb, Golden marketing.

Daly, M. (2007). Parenting in Contemporary Europe: A Positive Approach, Strasbourg, Council of Europe Publishing.

Davidov, M. i Grusec, J. E. (2006.), Untangling the Links of Parental Responsiveness to Distress and Warmth to Child Outcomes. Child Development, 77 (1): 44-58. doi:10.1111/j.1467-8624.2006.00855.x

DeBaryshe, B. D. (1995.), Maternal Belief Systems: Linchpin in Home Reading Process. Journal of Applied Developmental Psychology, 16 (1): 1-20. doi:10.1016/0193-3973(95)90013-6

Delale, E. A. i Pećnik, N. (2010.), Učestalost i međuodnosi korektivnih i preventivnih odgojnih postupaka majki djece predškolske dobi. Ljetopis socijalnog rada, 17 (1): 49-69.

Donahue, M. L., Pearl, R. i Herzog, A. (1997.), Mothers' Referential Communication with Preschoolers: Effects of Children's Syntax and Mothers' Beliefs. Journal of Applied Developmental Psychology, 18 (1): 133-147. doi:10.1016/S0193-3973(97)90019-8

Durrant, J. (2007.). Positive Discipline: What it is and How to Do it, Bangkok, Save the Children Sweden Southeast Asia and Pacific.

Gershoff, E. T. (2002.), Corporal Punishment by Parents and Associated Child Behaviours and Experiences: A Meta-Analytic and Theoretical Review. Psychological Bulletin, 128 (4): 539-579. doi:10.1037//0033-2909. 128.4.539

Grolnick, W. S., Deci, E. L. i Ryan, R. M. (1997.), Internalization within the Family: The Self-Determination Theory Perspective. U: J. E. Grusec i L. Kuczynski (ur.), Parenting and Children's Internalization of Values: A Handbook of Contemporary Theory (str. 135-161), New York: Wiley.

Harkness, S. i Super, C. M. (1996.), Introduction. U: S. Harkness i C. M. Super (ur.), Parents' Cultural Belief Systems: Their Origins, Expressions, and Consequences (str. 1-22), New York: The Guilford Press.

Hastings, P. D. i Grusec, J. E. (1998.), Parenting Goals as Organizers of Responses to Parent-Child Disagreement. Developmental Psychology, 34 (3): 465-479. doi:10.1037//0012-1649.34.3.465

Hoblaj, A. i Črpić, G. (2000.), Bitne vrednote u odgoju mladih naraštaja s posebnim osvrtom na školski vjeronauk. Bogoslovska smotra, 70 (2): 359-393.

Janković, J. (1998.), Vrednote u kontekstu obiteljskog sustava. Revija za socijalnu politiku, 5(1): 13-22.

Keller, H., Lohaus, A., Völker, S., Elben, C. i Ball, J. (2003.), Warmth and Attitudes Toward Parenting. Journal of Genetic Psychology, 164 (3): 275-292.

Lalière, C., Piret, M., Scohy, C. i Lambert, J. L. (2005.), La Négligence Parentale - Recherche action à l'Institut pour le Développement de l'Enfant et la Famille. Fribourg, Switzerland, Centre Universitaire de Pédagogie Curative. 
DRUŠ. ISTRAŽ. ZAGREB GOD. 20 (2011) BR. 3 (113),

STR. $625-646$

PEĆNIK, N., RADOČAJ, T. TOKIĆ, A.:

UVJERENJA JAVNOSTI...
Lee, Y. (2008.), Što je tjelesno kažnjavanje djece? Je li ono oblik nasilja? Dijete i društvo, 10 (1/2): 281-282.

LeVine, R. A., Miller, P. M. i West, M. M. (1988.), Parental Behavior in Diverse Societies. New Directions for Child Development, Vol. 40, San Francisco, Jossey-Bass.

Milas, G. (2005.), Istraživačke metode u psihologiji i drugim društvenim znanostima, Jastrebarko, Naklada Slap.

Morrow, V. (2003.), Perspectives on Children's Agency within Families: A View from a Sociology of Childhood. U: L. Kuczynsky (ur.), Handbook of Dynamics in Parent-Child Relations (str. 109-129), London: Sage Publications.

National Scientific Council on the Developing Child (2005.), Excessive Stress Disrupts the Architecture of the Developing Brain: Working Paper 3. http://www.developingchild.net (5. 10. 2009.).

Obiteljski zakon. Narodne novine, 162/1998.

Okagaki, L. i Bingham, G. E. (2005.), Parents' Social Cognitions and Their Parenting Behaviors. U: T. Luster i L. Okagaki (ur.), Parenting: An Ecological Perspective, 2nd edition (str. 3-33), London: Lawrence Erlbaum Associates.

Okagaki, L. i Divecha, D. J. (1993.), Development of Parental Beliefs U: T. Luster i L. Okagaki (ur.), Parenting: An Ecological Perspective (str. 35-67), Hillsdale, NJ: Erlbaum.

Pećnik, N. (2008.a), Suvremeni pogledi na dijete, roditeljstvo i socijalizaciju. Dijete i društvo, 10 (1/2): 99-115.

Pećnik, N. (2008.b), Istraživanje ponašanja, stavova i iskustava roditelja djece stare od 1 do 12 mjeseci: Izvješće o rezultatima. UNICEF, interni dokument.

Pennington, D. C. (2001.), Osnove socijalne psihologije, Jastrebarsko, Naklada Slap.

Richter, L. (2004.), The Importance of Caregiver-Child Interactions for the Survival and Healthy Development of Young Children. A Review, Geneva, World Health Organisation.

Schaffer, R. (1996.), Social Development, London, Blackwell Publishing.

Shonkoff, J. i Phillips, D. (2000.), From Neurons to Neighborhoods: The Science of Early Childhood Development, Washington, DC, National Academy Press.

Sigel, I. E. (1985.), A Conceptual Analysis of Beliefs. U: I. E. Sigel (ur.), Parental Belief Systems: The Psychological Consequences for Children (str. 345-371), Hillsdale, NJ: Erlbaum.

Slep, A. M. S. i O'Leary, S. G. (1998.), The Effects of Maternal Attributions on Parenting: An Experimental Analysis. Journal of Family Psychology, 12 (2): 234-243. doi:10.1037//0893-3200.12.2.234

St James-Roberts, I. (2007.), Helping Parents to Manage Infant Crying and Sleeping: A Review of the Evidence and Its Implications for Services. Child Abuse Review, 16 (1): 47-69. doi:10.1002/car.968

Suizzo, M. A., Chen, W. C., Cheng, C. C., Liang, A. S., Contreras, H., Zanger, D. i Robinson, C. (2008.), Parental Beliefs about Young Chil- 
DRUŠ. ISTRAŽ. ZAGREB GOD. 20 (2011),

BR. $3(113)$

STR. $625-646$

PEĆNIK, N., RADOČAJ, T., TOKIĆ, A.:

UVJERENJA JAVNOSTI. dren's Socialization across US Ethnic Groups: Coexistence of Independence and Interdependence. Early Child Development and Care, 178 (5): 467-486. doi:10.1080/03004430600823917

Williams, P. D., Williams, A. R., Lopez, M. i Tayko, N. P. (2000.), Mothers' Developmental Expectations for Young Children in the Philippines. International Journal of Nursing Studies, 37 (4): 291-301. doi:10.1016/S0020-7489(00)00004-3

\section{Citizens' Beliefs about Desirable Parental Behavior towards Young Children}

\author{
Ninoslava PEĆNIK \\ Faculty of Law, Zagreb \\ Tanja RADOČAJ \\ UNICEF Office in Croatia, Zagreb \\ Ana TOKIĆ \\ Faculty of Law, Zagreb
}

The aim of the research was to explore the Croatian citizens' beliefs about desirable parental behavior towards children younger than 3 years, and to examine if these could be predicted on the basis of several social-demographic variables. We collected the social-demographic data from the representative sample $(N=600)$, who also filled in the Questionnaire of beliefs about desirable parental practices towards young children. The results showed that, along with the most present belief about the importance of parental involvement, the belief about the importance of obedience and child subordination to adults was highly represented. Lower average agreement with corresponding statements was found for the beliefs justifying non-responsiveness to child's crying, corporal punishment and needlessness of induction (explanation of demands and prohibitions). Mentioned beliefs were found to be well predicted on the basis of social-demographic data, especially education level, followed by age, sex/gender and household income. This set of predictors was least successful in predicting belief about the importance of parental involvement, and most successful in predicting belief about needlessness of induction. Less educated and older citizens, with lower income, held beliefs that were inconsistent with contemporary scientific knowledge about optimal parental support to full realization of child's developmental potential.

Keywords: parental beliefs, parenting, social-demographic characteristics, corporal punishment, early child development 
DRUŠ. ISTRAŽ. ZAGREB GOD. 20 (2011)

BR. $3(113)$

STR. 625-646

PEĆNIK, N., RADOČAJ, T., TOKIĆ, A.:

UVJERENJA JAVNOSTI...

\section{Öffentlich vorherrschende Meinungen über korrekte Erziehungsmaßnahmen gegenüber Kleinkindern}

Ninoslava PEĆNIK

Rechtswissenschaftliche Fakultät, Zagreb

Tanja RADOČAJ

UNICEF-Büro in Kroatien, Zagreb

Ana TOKIĆ

Rechtswissenschaftliche Fakultät, Zagreb

Die vorliegende Untersuchung sollte ermitteln, welche elterlichen Erziehungsmaßnahmen nach Meinung kroatischer Erwachsener gegenüber Kleinkindern bis zu 3 Jahren wünschenswert sind. Des Weiteren sollte geprüft werden, ob elterliche Erziehungsmaßnahmen aufgrund unterschiedlicher soziodemografischer Variablen vorhersehbar seien. Im Rahmen der Untersuchung wurden die soziodemografischen Daten von 600 Teilnehmern gesammelt und ein eigens hierfür entworfener Umfragebogen zum Einsatz gebracht, der die Einstellung ermitteln sollte, welche elterlichen

Erziehungsmaßnahmen gegenüber Kleinkindern korrekł seien. Gemäß den Umfrageergebnissen ist die aktive Beteiligung an der Kindererziehung am allerwichtigsten, ebenfalls sehr hoch bewertet wird der Gehorsam des Kindes und seine Unterordnung unter die Anforderungen der Erwachsenen. Geringere Übereinstimmung herrscht hinsichtlich den Meinungen, dass es berechtigt sei, kindliches Weinen zu "überhören" und Kinder körperlich zu züchtigen, ferner dass es nicht notwendig sei, Anforderungen an das Kind bzw. Verbote zu erläutern (Induktion). Die genannten Einstellungen können aufgrund bestimmter soziodemografischer Merkmale prädiziert werden. Dazu gehören, in erster Linie, der Bildungsgrad der Eltern, ferner Geschlecht, Alter und Monatseinkommen sowie die Gesamtzahl der Familienmitglieder. Die erwähnte Gruppe soziodemografischer Prädiktoren lässt äußerst geringen Raum für die Einstellung, dass die aktive Beteiligung an der Erziehung des Kindes am allerwichtigsten sei, den meisten Raum hingegen für die Ansicht, dass Maßnahmen zur erzieherischen Induktion des Kindes nicht notwendig seien. Personen mit geringerem Bildungsgrad sowie ältere Personen mit geringerem Monatseinkommen zeigen verstärkt Ansichten, die weit hinter dem heutigen wissenschaftlichen Stand und den Erkenntnissen, wie wichtig ein angemessener elterlicher

Rückhalt bei der Verwirklichung des kindlichen

Entwicklungspotenzials ist, zurückstehen.

Schlüsselbegriffe: Einstellungen zu elterlichen Erziehungsmaßnahmen, soziodemografische Merkmale, körperliche Züchtigung, kindliche Frühentwicklung 